\title{
治験における長期入院時の被験者の 生活環境管理の検討
}

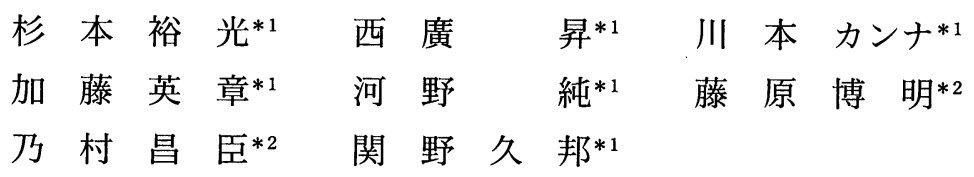

【目 的】

臨床第 I 相試験を実施する医療機関では、治験実 施計画書に従い規制された入院生活を被験者に課 しているのが現状であり、このことが被験者にス トレスを与えていると考えられる。本研究では当 クリニックで実施された 15 日間の長期入院を要 する治験において、被験者の生活環境管理を検討 し、被験者が受けるストレスとそれが他の各種検 査項目に与える影響について検討を行った。

【対 象・方 法】

1999 年 2 月から 1999 年 12 月に当クリニックで 実施された臨床第 I 相試験に参加し、プラセボ投 与を受けた被験者 9 名（25.56士3.78 歳; MEAN 士S.D.）を対象とした。上記の対象者は、いずれ も治験参加前に治験の内容について十分説明し、 文書による同意を取得した後に診察、生理学的検 査、臨床検査を行い、治験責任医師に治験参加に 問題ないと判断された。

被験者の入院期間は 15 日間、1 日の摂取カロリ

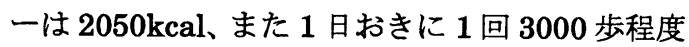
の散歩を実施した。入院日の翌々日を投薬第 1 日 目とし、生理学的検查は毎日、臨床検查は投薬直 前、投薬 2、3、7 および 14 日目の朝に実施した。

主要評価項目は、被験者が受けたストレスを評 価するため血清中コルチゾール、および血將中副 腎皮質刺激ホルモン（ACTH）とし、副次的評価 項目は体重、トリグリセライド(TG)、総コレステ ロール(TC)、クレアチンキナーゼ (CK)、アスパ

\footnotetext{
${ }^{* 1}$ 関野臨床薬理クリニック 干 171-0014 東京都豊島区池袋 3-28-3 *2 株式会社関野研究所
}

ルテイトアミノトランスフェラーゼ (AST)、ア ラニンアミノトランスフェラーゼ(ALT)とした。 評価項目の統計学的処理は、一元配置分散分析の 後にDunnett 法を用いて実施した。

なお、本治験の実施は、1999 年 1 月の関野臨 床薬理クリニック治験審査委員会で承認された。

\section{【結果】}

血清中コルチゾール、血漿中 ACTH 等の各種検査 項目の投薬直前值と投薬後值とをそれぞれ比較し たが、いずれの検査項目においても Dunnett 法で は有意な変化は認められなかった。（Fig1）

\section{【考察・結論】}

日本の高度経済成長に伴い、日本人の生活形態も 大きく変化した。特に都市化による生活環境の変 化、食生活の欧米化等による生活習慣の変化が、 日本人のストレスの増加や肥満の増加をもたらし、 それが成人病の増加につながっていることが示唆 されている。また、治験中に被験者がストレスを 受けた場合、生理学的検査、臨床検査に及ぼす影 響について㲘念されているが、そのことについて 検討した報告は少ない。

本研究では、15 日間の入院を要する臨床第 $\mathrm{I}$ 相 試験に参加した被験者が入院期間中に受けるスト レスとそれに伴う各種検查結果への影響を検討し たが、今回実施した血清中コルチゾール等の主要 項目に統計学的に有意な変動がみられなかったこ とより、長期入院拘束下においても被験者が受け るストレスをコントロールできるものと思われる。 また、被験者の生活環境を管理する一環として、 1 日の摂取カロリーを $2050 \mathrm{kcal}$ としたこと（通常、

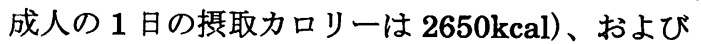




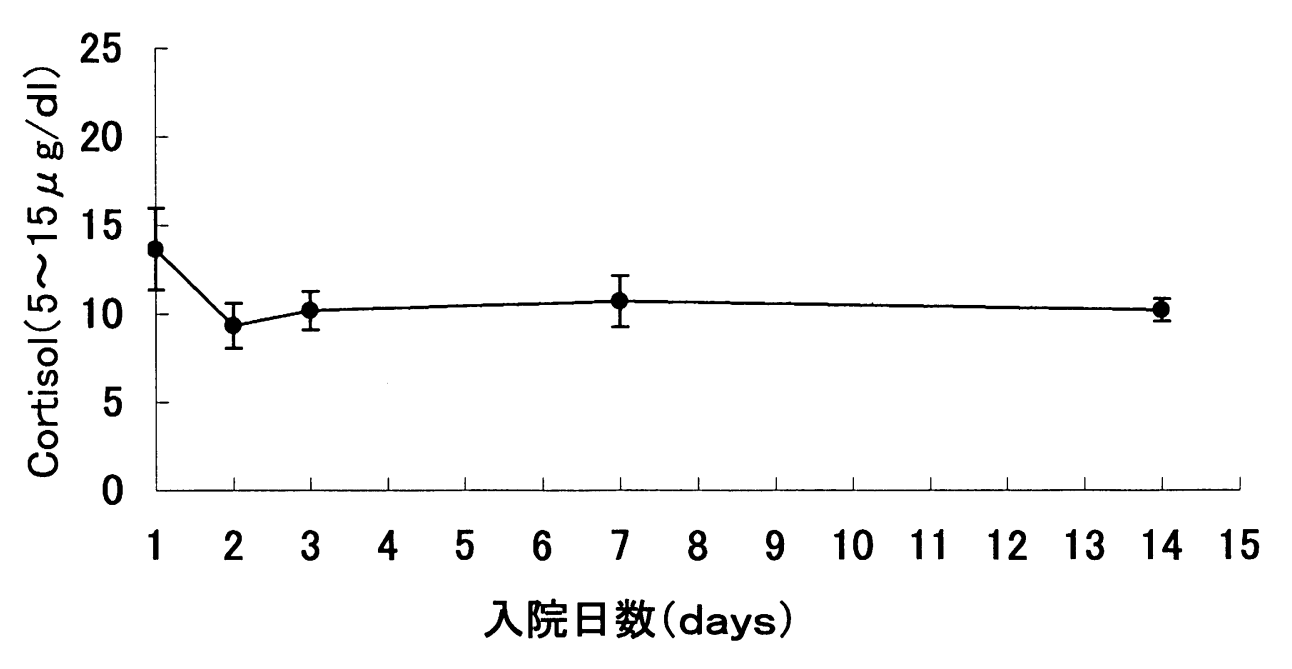

1 日おきに散歩を実施したが、体重、TG、TC、 CK 等の検查項目の推移に変化がみられなかった。 このことは、当クリニックが被験者に適切なカロ リーコントロールを実施していること、および筇 肉痛等の苦痛を催さない適度な運動を実施してい るものと考えられる。

以上のことから、当クリニックでは、治験実施 中の生活環境の管理が適切になされているものと 考える。 